\title{
BULLETIN OF THE
}

\section{AMERICAN \\ MATHEMATICAL SOCIETY}

Continuation of the Bulletin of the New York

Mathematical Society

\author{
A Historical and Critical Review \\ of Mathematical Science
}

Old Series: Bulletin of the Nkw Yurk Mathematical Society, Vols. I-III, 1891-1894.

New Series: Bulletin of the American Mathematical Society, Vols. I-X, 1894-1904.

\section{GENERAL INDEX \\ 1891-1904 \\ COMPILED BY}

Dr. EMILIE N. MARTIN

PUBLISHED FOR THE SOCIETY

BY

THE MACMILLAN COMPANY

LANCASTer, Pa., AND New YURK

1904 
Press of

Era Printing Company

LANCASTER, PA 


\section{CONTENTS}

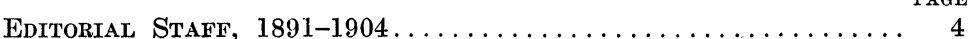

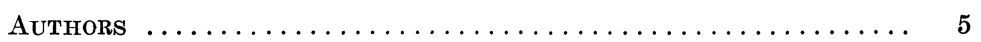

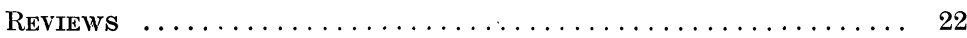

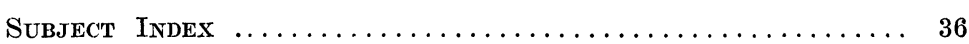

Authors of Papers Read before the Society, 1891-1904...... 74 